\title{
Judith Krawelitzki
}

\section{Gottes Macht im Psalter}

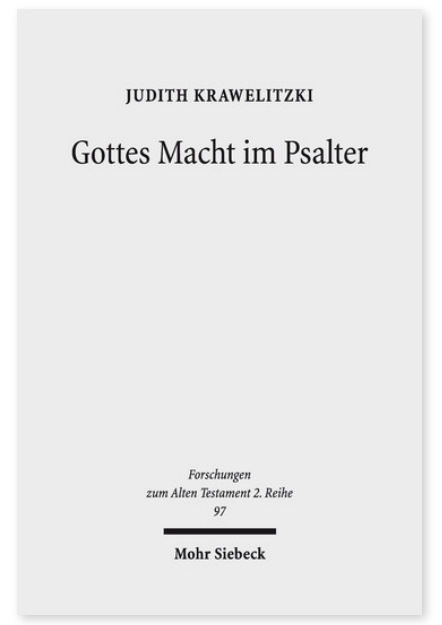

2017. XI, 319 Seiten. FAT II 97

ISBN 978-3-16-155780-4

DOI 10.1628/978-3-16-155780-4

eBook PDF $104,00 €$

ISBN 978-3-16-154570-2

fadengeheftete Broschur 104,00€
Judith Krawelitzki zeigt in dieser Studie, dass die explizite Rede von Gottes Macht im Psalter nicht nur ihren Schwerpunkt, sondern auch ihren Ursprung hat. Dort lassen sich drei eng miteinander verbundene Aspekte erkennen, unter denen Gottes Macht wahrgenommen worden ist: Macht als Wesenseigenschaft Gottes, Macht als Anteilgabe an den Menschen sowie Gottes Handeln in der Welt und am Menschen als Erweis seiner Macht. Entscheidend ist, dass Gottes Macht dem Wesen nach immer Rettungsmacht ist und darin Ausdruck seiner Liebe. Diese im Psalter ausgebildete Theologie hat die übrigen Schriften des Alten Testaments geprägt. Dabei ist eine deutliche Rückbindung an die Gebetssprache erhalten geblieben. Offenkundig hat Macht als Verstehens- und Deutungsrahmen für Gottes Wesen und Wirken nachhaltig erschließende Kraft gehabt.

Judith Krawelitzki Geboren 1982; 2001-09 Studium der Ev. Theologie, Latinistik und Italianistik; 2012-15 wiss. Mitarbeiterin an der Georg-August-Universität Göttingen; 2015 Promotion; 2015-17 Referendariat; derzeit Habilitationsprojekt in der Religionspädagogik.

Jetzt bestellen:

https://mohrsiebeck.com/buch/gottes-macht-im-psalter-9783161557804?no_cache=1 order@mohrsiebeck.com

Telefon: $+49(0) 7071-923-17$

Telefax: +49 (0)7071-51104 